\title{
Hæmodynamic Effects of Dipyridamole at Rest and During Exercise in Healthy Subjects
}

\author{
GEORGE A. BOUSVAROS, JOHN E. CAMPBELL, AND MAURICE McGREGOR \\ From the foint Cardiorespiratory Service and the Department of Radiology, Royal Victoria Hospital, \\ McGill University, Montreal, Canada
}

Dipyridamole (persantin) is a potent coronary vasodilator (Kadatz, 1959; Soloff, Giménez, and Winters, 1962) which, despite its production of a substantial increase in coronary flow in animals and man (West et al., 1962; Kinsella, Troup, and McGregor, 1962; Wendt et al., 1962), has been found relatively ineffective for the acute relief or prevention of angina pectoris (Foulds and Mackinnon, 1960; Kinsella et al., 1962; Russek and Howard, 1965). By contrast, nitroglycerin, the most efficient drug for the prophylaxis or treatment of the anginal attack, has not been shown to produce any sustained increase in coronary flow in patients with coronary heart disease (Gorlin et al., 1959).

There are several reasons that may explain this difference in therapeutic efficacy. Nitroglycerin may cause preferential increase of flow to ischæmic areas of the heart (Fam and McGregor, 1964). Alternatively, these drugs may evoke different energy demands through different effects on the peripheral circulation. Thus, higher heart rate or increased myocardial-fibre tension per beat would be expected to increase oxygen consumption. Tension per beat would vary with systolic blood pressure and inversely with ventricular diameter as determined by the La Place relationship. The hæmodynamic effects of nitroglycerin during rest and exercise have been reported elsewhere (Hoeschen et al., 1966). The object of this investigation was to make a comparable study of the effects of dipyridamole in an attempt to throw further light on the therapeutic differences between these two drugs. In addition, observations were made of the effect of both drugs on the heart size.

Received July 2, 1965.

* This work was supported by grants from the John A. Hartford Foundation (U.S.A.) and from the Medical Research Council of Canada (MT-1241).

\section{SUBJECTS AND METhodS}

The study was carried out in 9 healthy volunteers aged 28 to 58 years. Cardiac output was measured by a quantitative ear-oximetric technique developed and proved in this laboratory (McGregor, Sekelj, and Adam, 1961; Bousvaros et al., 1963). Blood pressure was measured via an indwelling needle in the brachial artery by Statham P23-D strain gauge and Sanborn No. 550 photographic amplifier recorder. Systolic and mean systolic arterial pressure, the latter obtained by planimetric integration, were used as a qualitative index of the changes in left ventricular pressure. Pressure time per minute was calculated as the product of mean systolic arterial pressure, heart rate, and systolic ejection period, measured from the brachial artery pressure tracing. This variable would also be expected to reflect qualitative changes in left ventricular pressure time per minute and hence of myocardial oxygen expenditure (Sarnoff $e t$ al., 1958). Left ventricular minute work was calculated in $\mathrm{kg}$. m./min., as follows: cardiac output (litres/min.) $\times$ mean systolic arterial pressure $(\mathrm{mm} . \mathrm{Hg}$ ) $\times 0.0136$.

"Control" exercise values were first obtained after 3 minutes of cycling in the sitting position at a constant rate of $300 \mathrm{~kg} . \mathrm{m} . / \mathrm{min}$. Subjects were allowed to rest for 20 minutes, after which the resting "control" measurements were made. Then $10 \mathrm{mg}$. of dipyridamole were administered intravenously over 1 minute, and 10 minutes later the resting "post-dipyridamole" values were obtained. Exercise began again at the same load and, after 3 minutes (i.e. 13 minutes after dipyridamole administration), "post-dipyridamole" exercise measurements were reported. This timing was chosen because it had been reported to coincide with the maximal hæmodynamic effects of the drug (Gebhardt et al., 1961; Hochrein, Schneider, and Sell, 1962).

In 8 of the subjects measurements of the transverse cardiac diameter were made from postero-anterior chest teleradiographs before and after dipyridamole, exactly as in the hæmodynamic study. Exposure time was 1 second at full inspiration, so as to eliminate changes due to cardiac and respiratory cycles, respectively. The form of exercise was different in that it consisted of 
TABLE I

HAMODYNAMIC EFFECTS OF DIPYRIDAMOLE (mean \pm standard error)

\begin{tabular}{|c|c|c|c|c|c|c|c|c|c|}
\hline & \multirow{2}{*}{$\begin{array}{c}\text { Cardiac } \\
\text { output } \\
\text { (litres/min.) }\end{array}$} & \multirow{2}{*}{$\begin{array}{c}\text { Heart } \\
\text { rate } \\
\text { (beats/ } \\
\text { min.) }\end{array}$} & \multirow{2}{*}{$\begin{array}{l}\text { Stroke } \\
\text { volume } \\
\text { (ml./beat) }\end{array}$} & \multicolumn{4}{|c|}{ Systemic arterial pressure $(\mathrm{mm} . \mathbf{H g})$} & \multirow{2}{*}{$\begin{array}{l}\text { Pressure } \\
\text { time/min. } \\
\text { (mm. Hg/ } \\
\text { sec./min.) }\end{array}$} & \multirow{2}{*}{$\begin{array}{c}\text { Left } \\
\text { ventricular } \\
\text { minute work } \\
\text { (kg. m./min.) }\end{array}$} \\
\hline & & & & Systolic & Diastolic & Mean & $\begin{array}{c}\text { Mean } \\
\text { syst. }\end{array}$ & & \\
\hline $\begin{array}{l}\text { Rest }(n=7) \\
\text { Control } \\
\text { Dipyridamole } \\
\Delta \text { per cent }\end{array}$ & $\begin{array}{l}4.96 \pm 0.27 \\
6.12 \pm 0.48 \\
+23.4 \star\end{array}$ & $\begin{array}{l}84 \pm 5 \\
82 \pm 5 \\
-2 \cdot 4\end{array}$ & $\begin{array}{l}60.6 \pm 4.6 \\
76.9 \pm 9.6 \\
+27\end{array}$ & $\begin{array}{c}103 \pm 4 \\
108 \pm 3 \\
+4 \cdot 8\end{array}$ & $\begin{array}{l}66 \pm 5 \\
65 \pm 4 \\
-1 \cdot 5\end{array}$ & $\begin{array}{l}80 \pm 4 \\
81 \pm 3 \\
+1 \cdot 2\end{array}$ & $\begin{array}{c}90 \pm 3 \\
93 \pm 3 \\
+3.3\end{array}$ & $\begin{array}{l}2220 \pm 165 \\
2224 \pm 107 \\
+0.002\end{array}$ & $\begin{array}{l}6 \cdot 1 \pm 0.42 \\
7.7 \pm 0.71 \\
+26.2 \star\end{array}$ \\
\hline $\begin{array}{l}\text { Exercise }(n=9) \\
\begin{array}{l}\text { Control } \\
\text { Dipyridamole }\end{array} \\
\begin{array}{l}\triangle \text { per cent } \\
\text {.. }\end{array}\end{array}$ & $\begin{array}{l}10 \cdot 71 \pm 1 \cdot 08 \\
12 \cdot 27 \pm 1.03 \\
\quad+14 \cdot 6 t\end{array}$ & $\begin{array}{c}108 \pm 3 \\
108 \pm 3 \\
0\end{array}$ & $\begin{array}{l}98 \cdot 5 \pm 7 \cdot 9 \\
112 \cdot 8 \pm 7 \cdot 7 \\
+14 \cdot 5\end{array}$ & $\begin{array}{c}125 \pm 5 \\
126 \pm 4 \\
+0 \cdot 8\end{array}$ & $\begin{array}{c}67 \pm 3 \\
64 \pm 3 \\
-4 \cdot 5\end{array}$ & $\begin{array}{c}88 \pm 4 \\
87 \pm 4 \\
-1 \cdot 1\end{array}$ & $\begin{array}{c}99 \pm 4 \\
99 \pm 4 \\
0\end{array}$ & $\begin{array}{c}3248 \pm 157 \\
3297 \pm 137 \\
+1.5\end{array}$ & $\begin{array}{l}14 \cdot 2 \pm 2 \cdot 1 \\
16 \cdot 7 \pm 1 \cdot 96 \\
+17 \cdot 6 \star\end{array}$ \\
\hline
\end{tabular}

$\star$ Statistically significant $(p<0.05)$

+ Statistically significant $(\mathrm{p}<0.02)$.

TABLE II

EFFECT OF DIPYRIDAMOLE AND NITROGLYCERIN ON TRANSVERSE CARDIAC DIAMETER (mm.), AT REST AND IMMEDIATELY AFTER EXERCISE

\begin{tabular}{|c|c|c|c|c|c|c|c|}
\hline & & Control & Dipyridamole & $\Delta$ per cent & Control & Nitroglycerin & $\Delta$ per cent \\
\hline $\begin{array}{l}\text { At rest } \\
\text { After exercise }\end{array}$ & $\because$ & $\begin{array}{l}138 \cdot 6 \pm 5 \cdot 5 \\
137.8 \pm 5 \cdot 6\end{array}$ & $\begin{array}{l}137 \cdot 6 \pm 5 \cdot 4 \\
139 \cdot 5 \pm 5 \cdot 6\end{array}$ & $\begin{array}{l}-0.7 \\
+1.2\end{array}$ & $\begin{array}{l}138 \cdot 1 \pm 5 \cdot 5 \\
138 \cdot 6 \pm 5 \cdot 5\end{array}$ & $\begin{array}{l}133.8 \pm 6.5 \\
133.6 \pm 5.7\end{array}$ & $\begin{array}{l}-3 \cdot 1^{\star} \\
-3 \cdot 6^{\star}\end{array}$ \\
\hline
\end{tabular}

^ Statistically significant $(p<0.05)$.
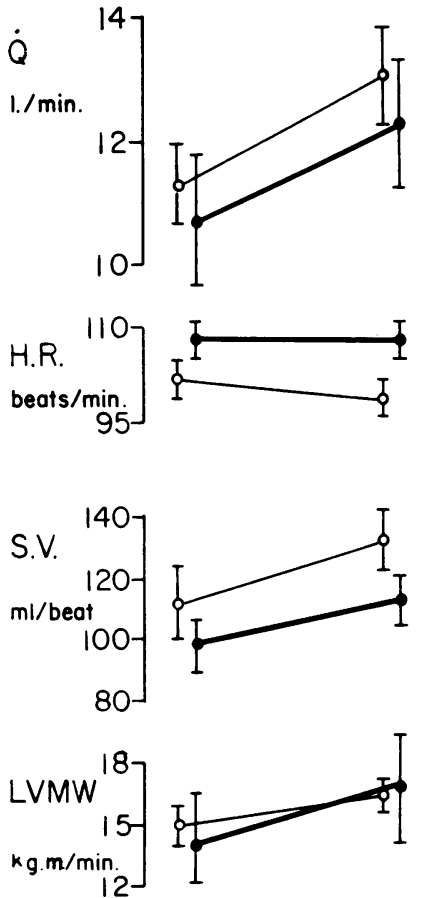
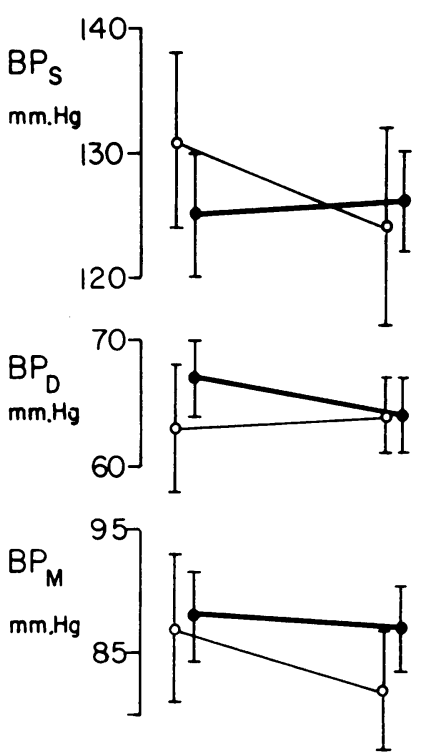
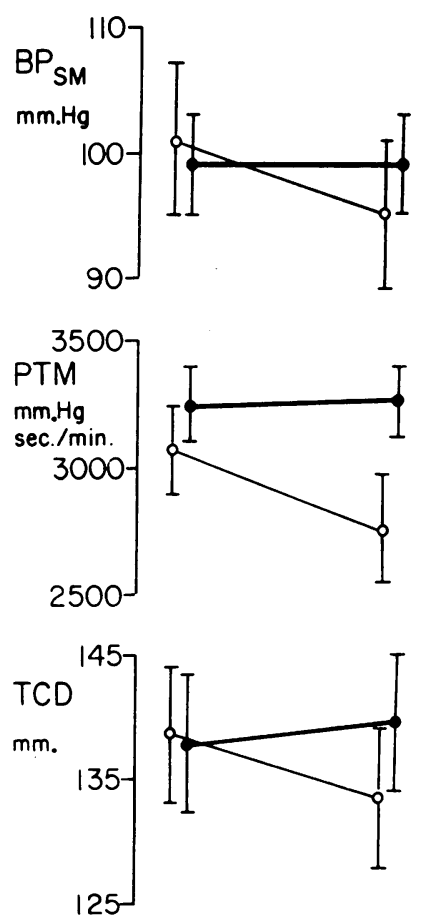

CONTROL DRUG

CONTROL

DRUG

$$
\multimap \text { NITROGLYCERIN } \longrightarrow \text { DIPYRIDAMOLE }
$$

FIGURE.-Changes (mean \pm standard error) during exercise, before and after administration of dipyridamole and of nitroglycerin. Q, cardiac output; H.R., heart rate; S.V., stroke volume; LVMW, left ventricular minute work; BPs,D,M,SM: systemic blood pressure, systolic, diastolic, mean and mean systolic; PTM, pressure time per minute; TCD, transverse cardiac diameter. Hæmodynamic data following nitroglycerin from Hoeschen et al. (1966). 
climbing a single $21-\mathrm{cm}$. step at a frequency estimated to result in a work rate of $300 \mathrm{~kg}$. $\mathrm{m}$. $/ \mathrm{min}$. in each subject. The step was placed immediately in front of the $x$-ray cassette so that there was minimal delay (6 to 9 seconds) between the end of climbing and the $x$-ray exposure. For comparison, teleradiograms were obtained under exactly similar conditions before and after administration of $0.6 \mathrm{mg}$. of nitroglycerin sublingually. Estimation of the transverse cardiac diameter was performed by one of us (J.E.C.), without knowledge of the sequence in which the 8 radiographs of each subject had been made.

\section{RESULTS}

In 7 subjects in whom data were available on the effects of dipyridamole at rest (Table I), there was a significant increase in cardiac output and left ventricular minute work. Average stroke volume was increased by 27 per cent, though this change was not statistically significant. There were negligible changes in heart rate and in systolic, diastolic, mean, and mean systolic arterial pressure and pressure time per minute.

The effects of dipyridamole were measured in 9 subjects during exercise (Table I and the Figure). There was a significant increase in cardiac output, stroke volume, and left ventricular minute work. All other measurements were virtually unaffected.

The effects of dipyridamole and nitroglycerin on the transverse cardiac diameter at rest and immediately after exercise are shown in Table II and the Figure. Nitroglycerin caused a significant decrease in diameter both at rest $(-3 \cdot 1 \%)$ and after exercise $(-3.6 \%)$. No significant change was observed after dipyridamole.

\section{Discussion}

Apart from the measurement of heart rate and cardiac output, all the methods employed in this study are of necessity indirect. However, it is probable that the direction of change in left ventricular systolic pressure and pressure time per minute may be rightly judged from the brachial pulse tracing and that changes in left ventricular dimensions may be judged from the transverse diameter of the heart. Though the technique of the latter measurement may appear crude, the standard deviation of differences between control measurements both at rest and during exercise was only $2.8 \mathrm{~mm}$., or 2 per cent of the average transverse diameter. The measurements made 6 to 9 seconds after exercise, however, probably do not represent the true values. Holmgren and Ovenfors (1960) reported an increase in radiological heart size during exercise in the sitting position that was not observed here, and it is possible that heart size had partially or completely returned to the resting value within six seconds of the end of exercise.
The increase in cardiac output without change in blood pressure or heart rate that was observed after dipyridamole administration in resting subjects in this study is in agreement with previous findings (Hochrein et al., 1962). However, the value of a drug for the relief of angina of effort should be related to the changes it causes during exercise. No reports have been published previously on the effects of dipyridamole in the exercising subject.

The energy demands on the myocardium, and hence the oxygen consumption, may be expected to increase in the presence of an increase in heart rate or an increase in the tension developed by each myocardial fibre. Changes in myocardial-fibre tension will vary with changes in systolic pressure in the absence of alteration in heart size. It has been stressed also that the duration of systole is relevant and that changes in oxygen consumption may be expected to vary with mean left ventricular systolic pressure per minute, the so-called "tension time index" (Sarnoff et al., 1958). In the exercising subject dipyridamole caused no change in heart rate, in systolic, diastolic, or systolic mean pressure, or in pressure time per minute, nor was there any detectable change in cardiac size. The only significant change was an increase in cardiac output, the result of increased stroke volume. As a consequence, left ventricular minute work also increased significantly.

Changes in these variables were similar to those that follow the administration of nitroglycerin to the exercising subject (Hoeschen et al., 1966; see the Figure). However, by contrast with dipyridamole, nitroglycerin caused some reduction in mean systolic pressure, pressure time per minute, and transverse diameter. Though these changes were small, they would tend to result in some reduction in myocardial-fibre tension and hence in oxygen consumption.

Thus, there are differences in the hæmodynamic effects of these two drugs in exercising man, which are consistent with their very different therapeutic effects when given before exercise in anginal subjects. The hæmodynamic differences appear small, however, and it is likely that the very different therapeutic efficacy depends upon other factors also, such as their reported different effects on the distribution of blood flow in ischæmic areas of the myocardium (Fam and McGregor, 1964).

\section{SUMMARY AND CONCLUSIONS}

The hæmodynamic effects of intravenous dipyridamole were studied in 9 healthy subjects at rest and during exercise. The effects of this drug on the transverse cardiac diameter also were studied at rest 
and immediately after comparable amounts of exercise, and were compared with the effects of nitroglycerin given sublingually. Dipyridamole caused an increase in cardiac output, stroke volume, and left ventricular minute work, both at rest and during exercise. It had no significant effect on heart rate, blood pressure, and pressure time per minute, nor on the transverse cardiac diameter. By contrast, cardiac diameter was slightly but significantly reduced after administration of nitroglycerin, both at rest and immediately after exercise. This, together with the previous observation that nitroglycerin causes a small reduction in systolic mean blood pressure and pressure time per minute, suggests that nitroglycerin may cause some reduction in myocardial oxygen consumption. This effect does not appear to be shared by dipyridamole.

Although the hæmodynamic effects of these two drugs are consistent with their respective therapeutic efficacy, the hæmodynamic differences are small and probably are not the sole reason for their different therapeutic effects.

We gratefully acknowledge the help of Dr. W. M. Fam in the radiological studies, and the technical assistance of Miss Judit Doman.

\section{REFERENCES}

Bousvaros, G. A., Palmer, W. H., Sekelj, P., and McGregor, M. (1963). Comparison of central and peripheral injection sites in the estimation of cardiac output by dye dilution curves. Circulat. Res., 12, 317.

Fam, W. M., and McGregor, M. (1964). Effect of coronary vasodilator drugs on retrograde flow in areas of chronic myocardial ischemia. Circulat. Res., 15, 355.

Foulds, T., and Mackinnon, J. (1960). Controlled doubleblind trial of "persantin" in treatment of angina pectoris. Brit. med. F., 2, 835.

Gebhardt, W., Dressel, J., Steim, H., and Reindell, H. (1961). Die Wirkung des 2,6-Bis (diaethanolamino)-4,8dipiperidino-pyrimido (5,4-d) pyrimidins auf den Kreislauf. Arzneimittel-Forsch., 11, 962.
Gorlin, R., Brachfeld, N., MacLeod, C., and Bopp, P. (1959). Effect of nitroglycerin on the coronary circulation in patients with coronary artery disease or increased left ventricular work. Circulation, 19, 705.

Hochrein, H., Schneider, K. W., and Sell, R. (1962). UUber die Wirkung 2,6-Bis (diäthanolamino)-4,8-dipiperidinopyrimido $(5,4-d)$ pyrimidin auf das suffiziente und insuffiziente Herz. Naunyn-Schmiedeberg's Arch. exp. Path. Pharmak., 243, 119.

Hoeschen, R. J., Bousvaros, G. A., Klassen, G. A., Fam, W. M., and McGregor, M. (1966). Hæmodynamic effects of angina pectoris, and of nitroglycerin in normal and anginal subjects. Brit. Heart $\mathcal{F}_{\text {., }}$ 28, 221.

Holmgren, A., and Ovenfors, C. O. (1960). Heart volume at rest and during muscular work in the supine and in the sitting position. Acta med. scand., 167, 267.

Kadatz, R. (1959). Die pharmakologischen Eigenschaften der neuen coronarerweiternden Substanz 2,6-Bis (diaethanolamino)-4,8-dipiperidinopyrimido (5,4-d) pyrimidin. Arzneimittel-Forsch., 9, 39.

Kinsella, D., Troup, W., and McGregor, M. (1962). Studies with a new coronary vasodilator drug: Persantin. Amer. Heart f., 63, 146.

McGregor, M., Sekelj, P., and Adam, W. (1961). Measurement of cardiac output in man by dye dilution curves using simultaneous ear oximeter and whole blood cuvette techniques. Circulat. Res., 9, 1083.

Russek, H. I., and Howard, J. C., Jr. (1965). Newer antianginal drugs. In Cardiovascular Drug Therapy; The Eleventh Hahnemann Symposium, ed. A. N. Brest and J. H. Moyer, p. 309. Grune and Stratton, New York and London.

Sarnoff, S. J., Braunwald, E., Welch, G. H., Jr., Case, R. B., Stainsby, W. N., and Macruz, R. (1958). Hemodynamic determinants of oxygen consumption of the heart with special reference to the tension-time index. Amer. f. Physiol., 192, 148.

Soloff, L. A., Giménez, J. L., and Winters, W. L., Jr. (1962). Experimental and clinical observations on 2,6-bis(diethanolamino)-4,8-dipiperidino-pyrimido-(5,4-d) pyrimidine (Persantin). Amer. F. med. Sci., 243, 783.

Wendt, V. E., Sundermeyer, J. F., denBakker, P. B., and Bing, R. J. (1962). The relationship between coronary blood flow, myocardial oxygen consumption and cardiac work as influenced by Persantin. Amer. F. Cardiol., 9, 449.

West, J. W., Bellet, S., Manzoli, U. C., and Müller, O. F. (1962). Effects of Persantin (RA8), a new coronary vasodilator, on coronary blood flow and cardiac dynamics in the dog. Circulat. Res., 10, 35. 